Annals of Tropical Research 29[1]:63-72(2007)

(C)LU, Leyte, Philippines

\title{
Survey and evaluation of promising mycoherbicides for the control of asyang [Mikania cordata (Burm.F.) B. L. Robinson]
}

\author{
Lualhati M. Noriel, Yolanda C. Mangaoang, Rodolfo A. Paningbatan, \\ Elizabeth P. Parac, and Rowena V. Salva \\ Department of Pest Management, College of Agriculture, \\ Leyte State University, Baybay, Leyte 6521-A, Philippines
}

\begin{abstract}
The study surveyed and collected diseased specimens of asyang [Mikania cordata (Burm. F.) B. L. Robinson] from various places of Leyte and Southern Leyte; isolated and identified the promising fungal pathogens (technically known as mycoherbicide) for the control of asyang; and determined the host range of the promising mycoherbicides.

Seventeen fungal isolates were found pathogenic to asyang with 4-9 days incubation period. The isolates from the towns of Capoocan (Cap), Matalom (Mat-2) and Tomas Oppus (TO) consistently caused significantly higher number of lesions per square leaf centimeter of leaf surface causing early death of leaves than the other isolates. Based on lesion and conidial characteristics, Cap isolate was identified as Cercospora mikaniacola Stevens while Mat-2 and TO isolates as Curvularia pallescens Ellis. Moreover, the promising isolates were also found non-pathogenic to different host plants tested.
\end{abstract}

Keywords: asyang, Mikania cordata, biological weed control, Cercospora mikaniacola, Curvularia pallescens, mycoherbicides

Correspondence: L. M. Noriel Address: Department of Pest Management, College of Agriculture, Leyte State University, Baybay, Leyte, 6521-A Philippines. Tel. No. (053) 3352626. DOI: $10.32945 /$ atr2915.2007 


\section{INTRODUCTION}

Mikania cordata [(Burm F.)B. L. Robinson] locally known as "asyang" in the Philippines is a creeping vine or climbing woody perennial vine belonging to Family Asteraceae. Its nodes found along the stems and branches easily form roots when these come in contact with the soil. It also produces seeds which can easily be disseminated by wind. The twining stems and entangled branches of asyang bear many leaves which form a mat that completely covers the crops and gradually smother them (Mercado, 1991).

In the Philippines, asyang is a very aggressive weed which is observed frequently in young secondary regrowth areas, along roadsides, fallow lands and in tree plantations and fruit tree orchards. It is a dominant weed species along hedgerows and in legume-planted fallow areas after rice specifically in Matalom, Leyte. It was also observed heavily infesting trees at the closedcanopy area of Mt. Pangasugan in Baybay, Leyte which is the major reason why this study was conceptualized.

Asyang can be effectively controlled by herbicide. However, their use is slowly minimized nowadays because of economic reason and the adverse effects on the environment and non-target organisms including man. Moreover, continuous herbicide application can cause development of weed resistance to herbicides. Asyang can also be controlled by manual and mechanical means but these methods prove laborious especially when dealing with large scale weed control.

Biological control of weeds using pathogenic fungi technically known as mycoherbicides offers opportunities for overcoming the above-mentioned inadequacies. Mycoherbicides are highly specific disease-inducing fungi isolated from diseased weeds and sprayed on fields to control specific target weed without harm to the crop or any non-target species in the environment. Watson (1992) has indicated that biological weed control, particularly the augmentation of the indigenous fungal pathogens has great potential impact to reduce chemical inputs and to prove viable, and more economical and effective control of weeds like asyang.

Two commercial mycoherbicides are available in the United States namely, COLLEGO and DEVINE. COLLEGO specifically controls northern jointvetch (Aeschynomene virginica L.) in rice and soybean. This consists of dried, living spores (conidia) of fungus Colletotrichum gloesporioides (Penz.) Sacc. f. sp. aeschynomene formulated as wettable powder. On the other hand, DEVINE is made up of spores of soil-borne fungus, Phytophthora 
palmivora (Butler). It is used for the control of strangler vine (Morremia odorata [H. and A.] Lind. L.) in citrus. Biomal is also registered in Canada as a mycoherbicide for the control of round-leafed mallow in field crops (Quimby and Walker, 1982).

In the Philippines particularly in ViSCA, Baybay, Leyte, biological weed control studies have been reported by Po (1996) specifically on the fungus Helminthosporium solani infecting itchgrass [Rottboella cochichinensis (Lour.) W.D. Clayton]. The fungus was able to reduce the vegetative and reproductive capacity of inoculated itchgrass compared with the uninoculated weed. Furthermore, Valleser (20050 reported the promising effects of Bipolaris sp. for the control of itchgrass. At IRRI, Alternaria sp. is found effective for the control of Sphenoclea zeynalica Gaerth, a broadleaf lowland rice weed (Mabbayad and Watson, 1993).

This study was done to conduct, survey and collect diseased asyang in selected places in Leyte and Southern Leyte; isolate and identify the promising fungal isolates (mycoherbicide) for the control of asyang and determine the host range of the promising mycoherbicides.

\section{MATERIALS AND METHODS}

\section{Survey, collection and isolation of fungal pathogens causing} disease of asyang

Different places of Leyte and Southern Leyte were surveyed for naturally occuring fungal disease of asyang. Infected plants were collected, placed in paper envelopes, labeled and brought to the laboratory for preliminary diagnosis

of the disease. Pathogens were isolated using the tissue planting method and maintained in potato dextrose agar (PDA) culture medium by serially transferring to new slants at 2-4 weeks intervals.

\section{Pathogenicity test of the fungal isolates}

Twenty (20) cm asyang cutting were planted in 10-cm diameter plastic pots for pathogenicity test of the different fungal isolates. Five replicate pots were provided per isolate.

Each fungal isolate was mass produced in flat bottles containing $30 \mathrm{ml}$ PDA. Spore suspension was prepared from 2-week old fungal culture by 
adding $30 \mathrm{ml}$ sterile water and 2 drops of Tween 80 per bottle. Spores per $\mathrm{ml}$ were counted and adjusted to a concentration of $10^{5} / \mathrm{ml}$ using a haemacytometer. Inoculation was done late in the afternoon by handspraying the young leaves of one month old asyang with $15 \mathrm{ml}$ of the prepared spore suspension per pot. The inoculated leaves were labeled and covered with plastic bag overnight and maintained thereafter outside the screenhouse. The incubation period, i.e. the number of days from inoculation to appearance of symptoms was determined. The characteristics of the lesion, and lesion number in $1 \mathrm{~cm}$ square area of sample leaf were noted. An index paper with a hole at the center equivalent to $1 \mathrm{~cm}$ square was used to determine the area. The percent disease severity of asyang inoculated with promising isolates was also noted starting at one week after inoculation up to 4 weeks. This was obtained from visual estimate of infected area as a percentage of the total area of leaf.

\section{Identification of the promising mycoherbicides}

Microscopic examination of diseased asyang leaves infected by the promising isolates identified as the Cap (Capoocan) and Mat-2 (Matalom) and TO (Tomas Oppus) isolates yielded abundant conidia and conidiosphores. The causal fungi were isolated into pure culture and examined under the microscope. Fungal colony growth and color in vitro were determined after 2 weeks of growth. Size, shape, color and number of septations of 50 randomly selected conidia of Cap and Mat-2 isolates (TO isolate was found similar to Mat-2 isolate) were determined. The "Keys to Species of Philippine Phytopathogenic Fungi" compiled by Quimio (1975) was used in keying out the genus and species of Curvularia sp. "A Monograph of the Fungus Genus Cercospora" by Chupp (1953) was used. The identification of the two promising isolates was confirmed by a Mycology expert of the University of the Philippines, Los Baños, Laguna.

\section{Host range test}

Different species of fruit and forest seedlings were tested to determine the host range of the most promising pathogenic isolates (Cap, Mat-2, TO) from asyang. These were obtained from the Department of Horticulture (Pomology) and at GTZ nursery in ViSCA. Likewise, additional crops such as cereals, ornamentals, rootcrops and vegetable crops were also included in the host-range test (Appendix Table 2). Two-week old fungal culture of the 
promising isolates was used and $10^{5} \mathrm{spores} / \mathrm{ml}$ concentration was inoculated by spraying into the new shoots of asyang and the seedlings of the different host plants with $15 \mathrm{ml} /$ pot of the prepared spore suspension. The inoculated seedlings were placed inside plastic chamber maintained at high relative humidity for two days. These were watered daily for the survival of the pathogens. The appearance of symptom was observed until 2 weeks after inoculation. The test was conducted in three trials.

\section{RESULTS AND DISCUSSION}

Isolation, identification and pathogenicity of fungal pathogens infecting asyang

Seventeen fungal isolates from various places in Leyte were found pathogenic to asyang with an average range of 4-9 days incubation period (Table 1). Of the seventeen isolates screened against asyang, three were found most pathogenic namely: Cap, Mat- 2 and TO. These three isolates consistently caused higher number of lesions per square centimeter of leaf area that significantly differ from other isolates (Table 2).

The identity of the three most pathogenic isolates (Cap, Mat-2, and TO) was determined based on the lesions, colony growth and characteristics of conidia. The Cap isolate identified as Cercospora mikaniacola Stevens formed $2 \mathrm{~mm}$ circular, gray lesion with white center. The colony growth in vitro appeared grayish white. On the other hand, the isolates from Mat-2 and TO were found to be similar and identified as Curvularia pallescens Ellis. The lesions formed were circular to irregular in shape with gray to black coloration and brown border. The lesion size is bigger than that of Cap isolate (approx. $5 \mathrm{~mm}$ or more). In vitro culture of $C$. pallescens exhibited black colony growth.

Conidial characteristics of the isolates e.g. conidial shape, septation, color and size (Fig. 1) observed from infected leaves and from pure culture revealed that the Cap isolate is typical of Cercospora mikaniacola and the Mat-2 and TO isolates are characteristic of Curvularia pallescens.

The Cap isolate revealed black colonies with conidiophores which are simple and arising in clusters and cylindrical obclavate, subhyaline conidia, with long obconically truncate base, 6-7 septa, and conidial measurement of 
Table 1. Incubation period (days) of the 17 fungal isolates after inoculation on Mikania cordata plants ${ }^{1 /}$

\begin{tabular}{llll}
\hline Fungal Isolates $^{2 /}$ & \multicolumn{3}{c}{ Incubation Period (day) $^{3 /}$} \\
\cline { 2 - 4 } & 1 & 2 & 3 \\
\hline Mah & $7.0 \mathrm{c}$ & $7.8 \mathrm{def}$ & $8.0 \mathrm{~b}$ \\
May blk. & $6.0 \mathrm{~d}$ & $6.0 \mathrm{~h}$ & $6.0 \mathrm{~d}$ \\
Cap & $6.0 \mathrm{~d}$ & $7.2 \mathrm{fg}$ & $7.0 \mathrm{c}$ \\
Maa blk. & $8.0 \mathrm{~b}$ & $8.0 \mathrm{cde}$ & $8.0 \mathrm{~b}$ \\
Mal blk. & $4.0 \mathrm{f}$ & $4.4 \mathrm{i}$ & $4.0 \mathrm{f}$ \\
TO & $8.0 \mathrm{~b}$ & $8.0 \mathrm{cde}$ & $8.0 \mathrm{~b}$ \\
Maa com & $5.0 \mathrm{e}$ & $5.0 \mathrm{i}$ & $5.0 \mathrm{e}$ \\
Mat com & $6.0 \mathrm{~d}$ & $7.0 \mathrm{~g}$ & $7.0 \mathrm{e}$ \\
Mal com & $7.0 \mathrm{c}$ & $8.4 \mathrm{a}-\mathrm{d}$ & $8.0 \mathrm{~b}$ \\
SL & $4.0 \mathrm{f}$ & $5.0 \mathrm{i}$ & $4.2 \mathrm{f}$ \\
Ab & $8.0 \mathrm{~b}$ & $7.4 \mathrm{efg}$ & $8.8 \mathrm{a}$ \\
Hin & $8.0 \mathrm{~b}$ & $8.6 \mathrm{abc}$ & $8.0 \mathrm{~b}$ \\
Hil & $9.0 \mathrm{a}$ & $8.8 \mathrm{ab}$ & $8.6 \mathrm{ab}$ \\
VB & $9.0 \mathrm{a}$ & $8.0 \mathrm{cde}$ & $8.2 \mathrm{ab}$ \\
B & $9.0 \mathrm{a}$ & $8.6 \mathrm{abc}$ & $8.6 \mathrm{ab}$ \\
Mer & $9.0 \mathrm{a}$ & $9.0 \mathrm{a}$ & $8.8 \mathrm{a}$ \\
Mat-2 & $8.0 \mathrm{~b}$ & $8.2 \mathrm{bcd}$ & $8.2 \mathrm{ab}$ \\
\hline
\end{tabular}

${ }^{1 /}$ Average of 5 replications

2/ Legend:

Mah- Mahaplag, Leyte

Hil - Hilongos

May blk. - Maybog (Black),Leyte

Cap - Capoocan

VB - Visca, Baybay

B - Baybay

Mer - Merida

Maa blk - Maasin (Black), So.Leyte

Mat-2 - Matalom (2)

TO - Tomas Oppus

Maa com - Maasin (Common)

Mat - Matalom (Common)

Mal - Malitbog (Common)

SL - Sri Lanka

$\mathrm{Ab}-$ Abuyog

Hin - Hindang

${ }^{3}$ In a column, means followed by common letters are not significantly different at $5 \%$ level by DMRT. 
Table 2. Number of leaf lesions per square $\mathrm{cm}$ of leaf area due to infection of the fungal isolates one month after inoculation on M. cordata plants (three trials) $\stackrel{1}{ }$

\begin{tabular}{llll}
\hline${\text { Fungal Isolates }{ }^{\prime \prime}}^{\prime}$ & \multicolumn{3}{c}{$\begin{array}{c}\text { Lesion Number }{ }^{3 /} \\
\text { TRIAL }\end{array}$} \\
\cline { 2 - 4 } & 1 & 2 & 3 \\
\hline Mah & $2.4 \mathrm{f}$ & $3.4 \mathrm{cde}$ & $3.6 \mathrm{ab}$ \\
May blk. & $4.4 \mathrm{de}$ & $4.0 \mathrm{cde}$ & $4 . \mathrm{bc}$ \\
Cap & $10.8 \mathrm{a}$ & $12.2 \mathrm{a}$ & $8.4 \mathrm{c}$ \\
Maa blk. & $4.8 \mathrm{~cd}$ & $3.6 \mathrm{cde}$ & $3.0 \mathrm{c}$ \\
Mal blk. & $3.4 \mathrm{def}$ & $3.2 \mathrm{cde}$ & $3.8 \mathrm{bc}$ \\
TO & $8.8 \mathrm{~b}$ & $8.4 \mathrm{~b}$ & $9.0 \mathrm{a}$ \\
Maa com & $2.4 \mathrm{f}$ & $3.2 \mathrm{cde}$ & $3.2 \mathrm{c}$ \\
Mat com & $6.2 \mathrm{c}$ & $4.0 \mathrm{cde}$ & $3.8 \mathrm{bc}$ \\
Mal com & $3.6 \mathrm{def}$ & $4.2 \mathrm{cde}$ & $3.4 \mathrm{c}$ \\
SL & $4.4 \mathrm{de}$ & $4.4 \mathrm{c}$ & $4.0 \mathrm{bc}$ \\
Ab & $5.0 \mathrm{~cd}$ & $4.0 \mathrm{cde}$ & $3.4 \mathrm{c}$ \\
Hin & $2.2 \mathrm{f}$ & $2.4 \mathrm{e}$ & $3.5 \mathrm{c}$ \\
Hil & $2.8 \mathrm{ef}$ & $2.6 \mathrm{de}$ & $2.8 \mathrm{c}$ \\
VB & $2.4 \mathrm{f}$ & $3.2 \mathrm{cde}$ & $3.2 \mathrm{c}$ \\
B & $2.6 \mathrm{f}$ & $3.4 \mathrm{cde}$ & $2.6 \mathrm{c}$ \\
Mer & $3.5 \mathrm{def}$ & $3.0 \mathrm{cde}$ & $4.0 \mathrm{bc}$ \\
Mat-2 & $7.8 \mathrm{~b}$ & $9.2 \mathrm{~b}$ & $5.4 \mathrm{~b}$ \\
\hline
\end{tabular}

1/ Average of 5 replications

2/ Legend:

Mah- Mahaplag, Leyte

Hil - Hilongos

May blk. - Maybog (Black),Leyte

Cap - Capoocan

VB - Visca, Baybay

Maa blk - Maasin (Black), So.Leyte

B - Baybay

Mal blk. - Malitbog (Black)

Mer - Merida

TO - Tomas Oppus

Mat-2 - Matalom (2)

Maa com - Maasin (Common)

Mat - Matalom (Common)

Mal - Malitbog (Common)

SL - Sri Lanka

$\mathrm{Ab}-\mathrm{Abuyog}$

Hin - Hindang

${ }^{3}$ In a column, means followed by common letters are not significantly different at $5 \%$ level by DMRT. 


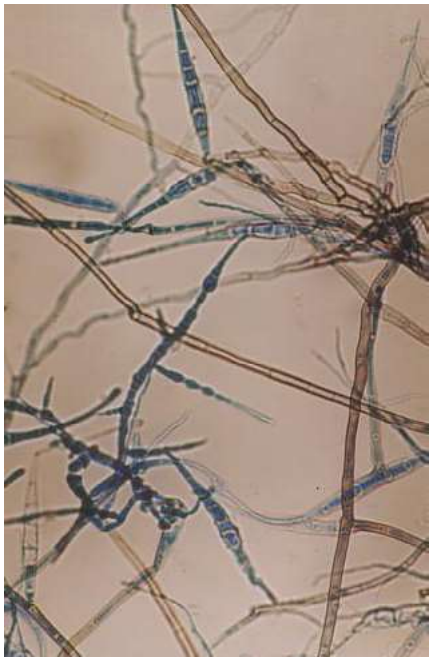

A

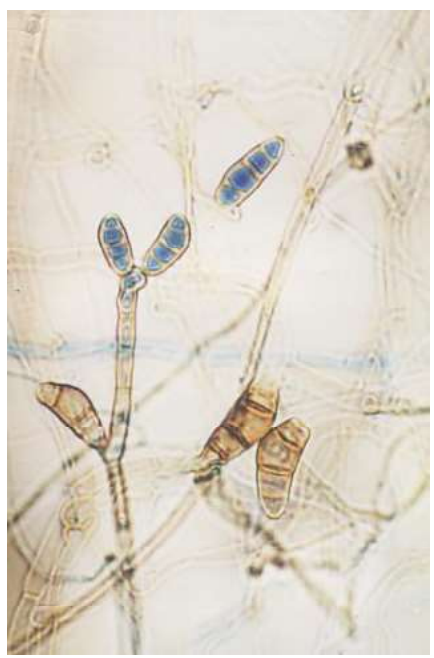

B

Figure 1. The conidia and conidiophore of Cercospora mikaniacola Stevens (A)and Curvularia pallescens Ellis (B) isolated from asyang in Capoocan, and Matalom and Tomas Oppus, Leyte, respectively.

A

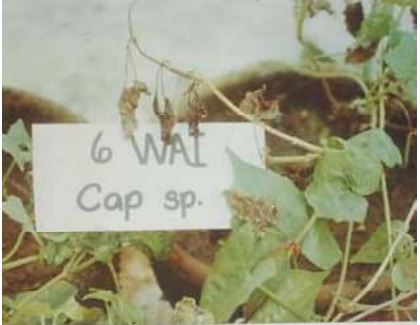

B

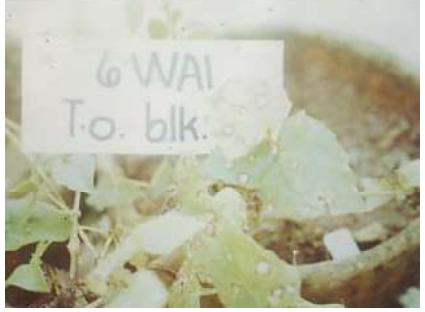

Figure 2. Photograph of the asyang plants taken 6 weeks after inoculation of fungal isolates. A-Cap isolate (Cercospora mikaniacola). B -TO isolate (Curvularia pallescens). Take note of the dead leaves of asyang inoculated with Cap isolate 6 weeks after inoculation (WAI). 
Table 3. Percent disease severity $\frac{1 /}{\text { on }}$ Mikania cordata plants taken starting one week after inoculation of the most pathogenic isolates ${ }^{2}$

\begin{tabular}{|c|c|c|c|c|}
\hline \multirow[t]{2}{*}{$\begin{array}{l}\text { Fungal } \\
\text { Isolates }\end{array}$} & \multicolumn{4}{|c|}{$\begin{array}{l}\text { Disease Severity \% }{ }^{3 /} \\
\text { Week after inoculation }\end{array}$} \\
\hline & 1 & 2 & 3 & 4 \\
\hline Cap & $54.0 \mathrm{a}$ & $72.0 \mathrm{a}$ & $88.0 \mathrm{a}$ & $100.0 \mathrm{a}$ \\
\hline Mat-2 & $46.0 \mathrm{a}$ & $58.0 \mathrm{~b}$ & $78.0 \mathrm{a}$ & $90.0 \mathrm{a}$ \\
\hline TO & $44.0 \mathrm{a}$ & $58.0 \mathrm{~b}$ & 76.0a & $92.0 \mathrm{a}$ \\
\hline
\end{tabular}

${ }^{1 /}$ Visual estimates based on leaf area infected with respect to the total leaf area

${ }^{2 /}$ Average of 5 replications.

${ }^{3 /}$ In a column, means followed by common letters are not significantly different at $5 \%$ level by DMRT

$55 \mu \mathrm{m}$ and $4.72 \mu \mathrm{m}$ wide. On the other hand, the Mat- 2 isolate produced gray colonies, simple brown conidiophores, 4-5 celled pale brown conidia with scarcely protuberant hilum. smooth-walled and median cell slightly curved. Conidia measured $25.24 \mu \mathrm{m}$ long and $10.43 \mu \mathrm{m}$ wide.

Regarding disease severity, results showed that the Cap isolate (C. mikanicola) was more pathogenic and aggressive than the Mat-2 and TO isolates (C. pallescens) causing significantly more severe leaf spots at 2 weeks after inoculation. Six weeks after inoculation the leaves of Cap-inoculated plants eventually died (Table 3 and Fig. 2).

\section{Host range studies}

Host range studies conducted in three trials using different species of fruit and forest tree seedlings, cereals, rootcrops, ornamentals and vegetable crops showed that promising mycoherbicides namely, C. mikaniacola and C. pallescens were not pathogenic to any of the test plants. Only asyang was found positive to infection. The host specificity of the two fungal isolates holds promise for their use as potential mycoherbicides for the control of asyang. 
Noriel et al.

\section{CONCLUSION}

The study has revealed the potential of using mycoherbicides for effective control of asyang. The fungal isolates from Capoocan and Matalom (and Tomas Oppus) are found to be the most promising mycoherbicides which are identified as Cercospora mikaniacola and Curvularia pallescens, respectively. Both fungal pathogens are also found host specific to asyang only.

\section{LITERATURE CITED}

CHUPP, C. 1953. A Monograph of the Fungus Genus CERCOSPORA. Ithaca, New York. 146-154 pp.

MABBAYAD, M. and A. K. WATSON. 1993. Biocontrol of Sphenoclea zeylanica Gaertn. with leaf blight pathogen.Proc. 24th Conference PMCP. Cebu City. May 4-7, 1993.

MERCADO, B. T. 1991. The Biology of Mikania cordata (Burm.F.) B.L. Robinson. UPLB Progress Report. NRCP Project. $56 \mathrm{p}$.

PO, M. P. 1996. Biological control of itchgrass (Roettboellia cochinchinensis Lour.) W. D. Clayton with Helminthosporium sp. BSA Thesis. ViSCA, Baybay, Leyte. 44 pp.

QUIMBY, P. C. JR. and H. L. WALKER. 1982. Pathogen as mechanism for integrated weed management. Weed Science (Suppl. 1) 30:30-34.

QUIMIO, T. H. 1975. A compilation: Keys to Species of Philippine Phytopathogenic Fungi (unpublished). 78 p.

VALLESER, V. C. 2005. Herbicidal potential of the culture filtrate of Bipolares sp. attacking Rottboellia cochinchinensis (Lour.) W. D. Clayton. BSA Thesis, LSU, ViSCA, Baybay, Leyte. 54 pp.

WATSON, A. K. 1992. Current status of bioherbicide development and prospects for rice in Asia. In: Proceedings of the International Symposium on Biological Control and Integrated Management of Paddy and Aquatic Weeds in Asia. 367$370 \mathrm{pp}$. 